Wahyu Kurniawan, Karjuni Dt. Maanil Implementasi Kebijakan Pembangunan Infrastruktur Jalan di Kecamatan Tabir Selatan Kabupaten Merangin dengan Menggunakan Model Donald Van Metter dan Carl Van Horn

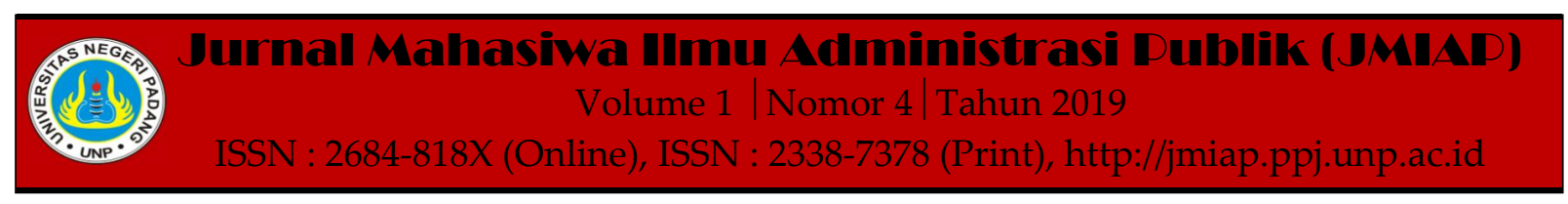

\title{
IMPLEMENTASI KEBIJAKAN PEMBANGUNAN INFRASTRUKTUR JALAN DI KECAMATAN TABIR SELATAN KABUPATEN MERANGIN DENGAN MENGGUNAKAN MODEL DONALD VAN METTER DAN CARL VAN HORN
}

\author{
Wahyu Kurniawan ${ }^{1(a)}$, Karjuni Dt. Maani ${ }^{2(b)}$ \\ ${ }^{1}$ Jurusan Ilmu Administrasi Negara, Universitas Negeri Padang \\ ${ }^{2}$ Jurusan Ilmu Administrasi Negara, Universitas Negeri Padang \\ a)wahyu6232@gmail.com, ${ }^{b}$ karjuni.dtmaani@fis.unp.ac.id
}

\begin{abstract}
Policy implementation are actions taken by individuals or groups of government or private sector to achieve the goals specified in previous policy decisions. This study was designed to describe the six variables of the Donald Van Metter and Carl Van Horn models in the implementation of road infrastructure development policies in the South Tabir District of Merangin Regency which connects Gading Jaya village with Muara Delang village. This type of research is a qualitative descriptive study. There are variable models of Donald Van Metter and Carl Van Horn, standard; destination; and policy objectives, resources, characteristics of implementing organizations, implementers' attitudes, communication between organizations, socio-economic and political environments. PT. SAL and PT. Shogun Judging from the six variables in the Donald Van Metter and Carl Van Horn models in the implementation of road infrastructure development in the South Tabir District has been successfully carried out. This can be seen from having been built with number one quality increased $8.2 \mathrm{Km}$. This construction has been carried out from 2017 to 2019 with the target of road construction as far as $9.3 \mathrm{Km}$.
\end{abstract}

Keywords : Policy Implementation, Development, Road Infrastructure

Corresponding author. Email.wahyu6232@gmail.com,karjuni.dtmaani@fis.unp.ac.id

How to cite this article. Kurniawan, W \& Dt. Maani, K. (2019). Implementasi Kebijakan Pembangunan Infrastruktur Jalan di Kecamatan Tabir Selatan Kabupaten Merangin dengan Menggunakan Model Donald Van Metter dan Carl Van Horn. Jurnal Mahasiwa Ilmu Administrasi Publik (JMIAP) Jurusan Ilmu Administrasi Negara Fakultas Ilmu Sosial Universitas Negeri Padang, Volume 1 (4), Hal. 67-78. http://jmiap.ppj.unp.ac.id

ISSN : 2684-818X (Online), ISSN : 2338-7378 (Print)

Copyright $\bigcirc 2019$. Published by Pusat Kajian-Pemberdayaan dan Pelayanan Masyarakat (PK-P2M) FIS UNP Padang 


\section{PENDAHULUAN}

Salah satu aspek yang sangat penting dalam mempercepat pembangunan nasional adalah melalui pembangunan infrastruktur. Peran Infrastruktur yang utama adalah sebagai roda penggerak kemajuan dan kesejahteraan masyarakat baik pada bidang ekonomi, kesehatan, pendidikan maupun diberbagai kegiatan sosial lainnya. Hal ini dikarenakan kemajuan dan pertumbuhan ekonomi tidak dapat dipisahkan dari adanya infrastruktur seperti telekomunikasi, sanitasi, transportasi, dan energi. Oleh karena itu, pembangunan infrastruktur ini menjadi dasar yang kuat dalam pembangunan pertumbuhan ekonomi untuk masa yang akan datang.

Perekonomian suatu daerah jika didukung dengan pelayanan infrastruktur yang baik, maka perekonomian suatu daerah tersebut akan mengalami peningkatan yang sangat cepat. Selain itu barang dan jasa yang dihasilkan akan menjadi lebih baik (Hadi Wahyono,2006).

Desa Muara Delang merupakan salah satu desa yang menjadi tempat jual beli yang cukup besar di Kecamata Tabir Selatan, Kabupaten Merangin, Bangko Provinsi Jambi. Desa Muara Delang banyak mendatangkan barang-barang kebutuhan masyarakat dari luar daerah seperti barangbarang sembako dari pulau Jawa, sayursayuran dari Kerinci dan berbagi jenis ikan didatangkan dari Sumatera Barat. Akses jalan menuju desa Muara Delang cukup memprihatinkan terutama saat musim hujan dan kemarau tiba. Saat musim kemarau jalanan penuh dengan debu akibatnya para pengendara sulit melihat jalan terutama bagi pengendara sepeda motor. Selanjutnya saat musim penghujan tiba, jalanan berlumpur dan becek, banyak kendaraan yang terperosok keluar badan jalan (Tribun jambi.com. september, 2017).

Kondisi jalan yang memprihatinkan saat musim hujan memberikan dampak terhadap perekonomian masyarakat, dimana terjadi keterlambatan pemasokan sembako, sayursayuran dan ikan ke desa Muara Delang. Akibatnya harga sembako, sayur-sayuran dan ikan didesa Muara Delang meroket naik. Selain dibidang perekonomian, akses jalan juga sangat penting dalam bidang pendidikan, kesehatan dan juga sosial. Dalam bidang pendidikan misalnya, bagi pelajar yang bersekolah dibatas kota kondisi jalan yang memprihatikan sangat menggagu proses belajar dan juga membahayakan keselamatan. Selanjutnya, kesulitan akses jalan terutama saat musim hujan dibidang kesehatan menuju rumah sakit di kota juga mempengaruhi keselamatan masyarakat. Belum lagi apa bila musim liburan tiba, masyarakat sulit untuk pergi berlibur ke kota.

Dengan adanya pembangunan infrastruktur jalan, diharapkan para pengguna jalan dapat memanfaatkan dan menggunakan jalan sebagai akses untuk mempermudah dan memperlancar berbagai kegiatan seperti mobilisasi barang dan jasa, pemasaran hasil pertaniannya, mangangkut hasil pertanian dan lain sebagainya ( Soetomo, 2008 ). Fungsi jalan harus dipertahankan dengan baik melalui pemeliharaan dan perawatan jalan secara berkala. Hal ini karena, jalan mempunyai peran yang sangat penting dalam mendukung perkembangan dan kemajuan kegiatan sosial, ekonomi, budaya, pertahanan dan keamanan. (Kepastian Walid, 2016).

Kesejahteraan masyarakat, baik dalam bidang sosial ekonomi, kesehatan dan peningkatan mutu pendidikan dapat sukses dan berhasil salah satunya disebabkan karena adanya pembangunan infrastruktur jalan. Melalui pembangunan infrastruktur jalan pendapatan penduduk desa akan bertambah ditambah lagi dengan mobilitas masyarakat dan barang yang lancar. Hal ini sesuai dengan RPJMD Merangin untuk lima tahun kedepan (2019-2023), yang 
Wahyu Kurniawan, Karjuni Dt. Maani| Implementasi Kebijakan Pembangunan Infrastruktur Jalan di Kecamatan Tabir Selatan Kabupaten Merangin dengan Menggunakan Model Donald Van Metter dan Carl Van Horn

dituangkan dalam peraturan daerah Kabupaten Merangin nomor 3 tahun 2019 dengan bervisi misikan "Merangin Mantap 2023 Unggul dibidang Pertanian dan Pariwisata" dengan mengembangkan perekonomian daerah berbasis sumberdaya bidang pertanian, perikanan, dan pariwisata, meningkatkan pembangunan inftastruktur pelayanan dasar berwawasan lingkungan, mengembangkan sumber daya manusia yang berdaya saing, memantapkan tata kelola Pemerintahan yang efektif, bersih dan melayani menuju world Class Government.

Peniliti ingin mengetahui sejauh mana implementasi kebijakan di bidang pembangunan jalan yang telah di lakukan oleh pemerintah daerah dan berbagai pihak yang terkait dalam pembangunan jalan disesa Muara Delang dengan monggunakan model Donald Van Metter Dan Carl Van Horn yang didasrkan pada enam buah variabel seperti 1). Standar dan sasaran kebijakan, 2). Sumber daya, 3). Karakteristik organisasi pelaksana, 4). Sikap para pelaksana, 5). Komunikasi antar organisasi terkait dan kegiatan-kegiatan pelaksanaan, 6). Lingkungan sosial, ekonomi dan politik.

Dari latar belakang masalah di atas, maka penulis merasa tertarik untuk melakukan penelitian dengan judul: Implementasi Kebijakan Pembangunan Infrastruktur Jalan Di Kecamatan Tabir Selatan Kabupaten Merangin Dengan Menggunakan Model Donald Van Metter Dan Carl Van Horn.

\section{TINJAUAN PUSTAKA}

\section{Konsep Implementasi Kebijakan}

Implementasi kebijakan adalah suatu tindakan yang dilakukan untuk mencapai suatu tujuan. Implementasi kebijakan biasanya dilakukan oleh suatu individu, lembaga pemerintahan ataupun suwasta. Implementasi berhubungan dengan berbagai kegiatan yang difokuskan pada terlakasanya program. Dalam hal ini diperlukan suatu administrasi yang dapat mengatur atau mengorganisir kebijakan, menginterpretasikan serta menerapkan kebijakan yang sudah disepakati sebelumnya (Harbani, 2010).

Implementasi kebijakan merupakan suatu proses penterjemahan peraturan kedalam bentuk tindakan sehingga dalam praktiknya implementasi kebijakan dapat dikatakan sebagai suatu proses yang sangat kompleks dan bermuatan politis karena ada pengaruh dari berbagai kepentingan (Agustino, 2016).

Menurut Pulzl and Treib sejarah perkembangan implementasi kebijakan publik terdapat tiga generasi perkembangan di mulai tahun 1970-an hingga sekarang. Dapat kita ketahui bahwa teori implementasi kebijakan yang pertama adalah teori top-down atau disebut juga topdowner atau fordwar-mapping merupakan teori implementasi kebijakan yang pada saat itu dijadikan sebagai tonggak awal implementasi. Hal ini dilakukan untuk menjawab pertanyaan mengapa implementasi banyak mengalami kegagalan dan bagaimana menghasilkan formula implementasi yang memiliki tingkat kegagalan yang rendah. Teori top-dawn ini dikembangkan oleh beberapa sarjana Wildsky, Van Matter dan Van Horn, Mazmanian dan Sabatier. Teori top down memiliki kekurangan dimana pada teori ini masih menitik beratkan pada sudut pandang pembuat kebijakan dan pendekatan perspektif yang digunakan bersifat terbatas pada ruang dan waktu.

\section{Model Implementasi Kebijakan Donald Van Metter dan Carl Van Horn}

$$
\text { A Model of the Policy }
$$

Implementation merupakan implementasi kebijakan yang dirumuskan Van Metter dan Van Horn dalam Endah, (2017). Melalui berbagai variabel proses implementasi ini 
Wahyu Kurniawan, Karjuni Dt. Maani| Implementasi Kebijakan Pembangunan Infrastruktur Jalan di Kecamatan Tabir Selatan Kabupaten Merangin dengan Menggunakan Model Donald Van Metter dan Carl Van Horn

merupakan kegiatan yang dilakukan untuk meraih kinerja implementasi kebijakan yang tinggi. A Model of the Policy Implementation mengandaikan bahwa implementasi kebijakan berjalan secara linear dari keputusan politik, pelaksana dan kinerja kebijakan publik. Model ini menjelaskan bahwa kinerja kebijakan dipengaruhi oleh beberapa variabel yang saling berkaitan, variable-variabel tersebut yaitu: (Agustino, 2016 ) : 1). Standar dan sasaran kebijakan, 2). Sumber daya, 3). Karakteristik organisasi pelaksana, 4). Sikap para pelaksana, 5). Komunikasi antar organisasi terkait dan kegiatan-kegiatan pelaksanaan, 6). Lingkungan sosial, ekonomi dan politik. Keenam variabel pada donald van netter dan carl van horn dapat dilihat pada Gambar di bawah ini.

\section{Gambar 1. Variabel pada Model Donald Van Metter dan Carl Van Horn}

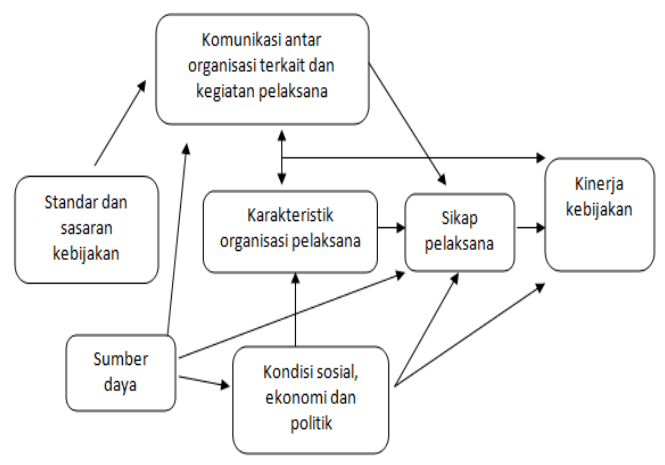

Sumber : Van Metter \& Van Hom (Agustino, 2016)

Variabel-variabel dalam implementasi kebijakan publik model Van Meter dan Van Horn dijelaskan sebagai berikut:

a) Standar, Tujuan dan sasaran kebijakan

Pengukuran tingkat keberhasilan dari kinerja implementasi kebijakan dapat diukur melalui tujuan kebijakan yang ada di level pelaksana kebijakan yang bersifat realistis dengan sosio-kultur. Jika ukuran dan dan sasaran kebijakan yang akan diterapkan terlalu ideal (utopis), maka kebijakan tersebut akan sulit untuk direalisasikan (Agustino, 2016). Van Meter dan Van Horn mengemukakan bahwa :

"Untuk mengukur kinerja implementasi kebijakan harus menegaskan pada standar dan sasaran tertentu yang harus dicapai oleh para pelaksana kebijakan, kinerja kebijakan pada dasarnya merupakan penilaian atas tingkat ketercapaian standar dan sasaran tersebut" (Sulaeman, 1998).

b) Sumber daya

Keberhasilan implementasi kebijakan bergantung pada kemampuan untuk memanfaatkan sumber daya yang tersedia. Tiga sumber daya yang harus diperhatikan dalam melaksanakan implementasi kebijakan adalah sember data manusia, finansial, dan waktu. Manusia merupakan sumber daya yang paling penting dalam penentuan keberhasilan suatu implementasi kebijakan. Adanya sumber daya manusia yang berkualitas sesuai dengan pekerjaan yang diisyaratkan oleh kebijakan yang telah ditetapkan secara apolitik dituntut dalam setiap tahap implementasi. Sumber daya finansial menentukan keterlaksananya suatu kebijakan. Jika sumber daya finansial bermasalah maka implementasi kebijakan akan terganggu atau bahkan terhambat. Donald Van Mater dan Van Horn (dalam Widodo 2008) menegaskan bahwa: "Sumber daya kebijakan (policy resources) tidak kalah pentingnya dengan komunikasi. Sumber daya kebijakan ini harus juga tersedia dalam rangka untuk memperlancar administrasi implementasi suatu kebijakan. Sumber daya ini terdiri atas dana atau insentif lain yang dapat memperlancar pelaksanaan suatu kebijakan terbatasnya dana atau insentif lain dalam implementasi kebijakan merupakan sumbangan besar terhadap gagalnya implementasi kebijakan." 
Jika kita urut satu persatu terkait rumusan para ahli tentang makna dan hakikat implementasi bagi sebuah program tentu makalah ini akan menjadi begitu panjang, maka dalam kesempatan ini dapat kita tegaskan bahwa Implementasi merupakan istrumen yang begitu penting bagi pemerintah sebagai implementator dalam mencapai tujuan -tujuan dan kesepakatan program yang telah di sepakati atau yang telah dirumuskan.. Dengan kata lain berhasil atau tidak berhasilnya sebuah program tergantung dari seberapa sukses program tersebut dapat di implementasikan dan sebera besar pula efek yang didapat dari implementasi program tersebut.(Adil Mubarak, 2012).

\section{c) Karakteristik Organisasi Pelaksana}

Agen pelaksana kebijakan yang terlibat meliputi organisasi formal maupun organisasi informal. Kinerja implementasi kebijakan dari organisasi pelaksana dipengaruhi oleh ciri yang tepat serta cocok dengan para agen pelaksananya. Hal ini berkaitan dengan konteks kebijakan yang akan dilaksanakan. Pelaksana kebijakan dituntut agar ketat dan disiplin pada beberapa kebijakan. Pada konteks lain diperlukan agen pelaksana yang demokratis dan persuasif. Penentuan agen pelaksana kebijakan juga dipengaruhi oleh cangkupan atau luas wilayah kebijakan.

d) Komunikasi antar Organisasi Terkait dan Kegiatan-Kegiatan Pelaksanaan

Standar dan tujuan implementasi kebijakan harus dikomunikasikan dengan baik kepada para agen pelaksana. Oleh karena itu, Donald Van Mater dan Carl Van Horn (dalam Widodo 2008) mengatakan bahwa : "apa yang menjadi standar tujuan harus dipahami oleh setiap implementors.

e) Disposisi atau Sikap Para Pelaksana
Menurut pendapat Van Metter dan Van Horn dalam Agustinus (2006) "sikap penerimaan atau penolakan dari agen pelaksana kebijakan sangat mempengaruhi keberhasilan atau kegagalan implementasi kebijakan publik. Hal ini sangat mungkin terjadi karena kebijakan yang dilaksanakan bukanlah hasil formulasi warga setempat yang mengenal betul permasalahan dan persoalan yang mereka rasakan. Tetapi kebijakan publik biasanya bersifat top down yang sangat mungkin para pengambil keputusan tidak mengetahui bahkan tak mampu menyentuh kebutuhan, keinginan atau permasalahan yang harus diselesaikan".

Sikap para pelaksana dipengaruhi oleh bagaimana pendangan dan cara melihat mereka terhadap pengaruh kebijakan kepentingan-kepentingan organisasi dan kepentingan-kepentingan pribadinya. Van Mater dan Van Horn (1974) menjelaskan bahwa implementasi kebijakan diawali dengan befiltered (penyaringan) lebih dahulu dari persepsi para pelaksana (implementors) dan dalam batas mana kebijakan itu akan dilaksanakan. Ada tiga macam elemen respon yang dapat mempengaruhi kemampuan dan kemauan dari para pelaksana untuk melaksanakan suatu kebijakan, antara lain yaitu : 1)Pengetahuan (cognition), pemahaman dan pendalaman (comprehension and understanding) terhadap kebijakan,2) arah respon mereka apakah menerima, netral atau menolak (acceptance, neutrality, and rejection), dan 3), intensitas terhadap kebijakan.

f) Kondisi Lingkungan sosial, ekonomi dan politik

Dalam menilai kinerja implementasi kebijakan hal terakhir yang harus kita perhatikan adalah melihat sudah sejauh 
mana lingkungan eksternal ikut mendorong keberhasilan kebijakan. Lingkungan eksternal yang dimaksud mencakup lingkungan sosial, ekonomi dan politik. Kondisi lingkungan eksternal yang tidak kondusif dapat menjadi penyebab kegagalan kinerja implementasi kebijakan. Karena itu, perlu adanya upaya untuk membuat kondisi lingkungan eksternal menjadi kondusif agar implementasi kebijakan dapat berjalan lancar.

\section{g) Perencanaan Pembangunan Infrastruktur}

Pembangunan merupakan uapaya untuk meningkatkan segenap sumber daya melalui prinsip daya dan hasil guna secara terencana, berkelanjutan, merata dan berkeadilan. (Bachtiar, 2002). Dalam undang-undang nomor 38 tahun 2004 tentang Jalan, bahwa infrastruktur jalan mempunyai peran penting dalam bidang ekonomi, politik, sosial-budaya, pertahanan dan keamanan, lingkungan hidup, serta dipergunakan untuk sebesar-besar kemakmuran rakyat. Jalan sebagai prasarana distribusi barang, jasa dan manusia merupakan faktor yang penting dalam kehidupan, tanpa adanya akses jalan yang baik maka segala katifitas manusia di berbagai bidang kehidupan akan terhambat. Jalan merupakan satu kesatuan sistem jaringan yang menghubungkan dan mengikat seluruh wilayah Republik Indonesia. Menurut Peraturan Pemerintah nomor 34 tahun 2006 menjelaskan jalan berdasar peruntukannya terdiri atas jalan khusus dan jalan umum. Jalan umum dikelompokkan menurut sistem (primer dan sekunder), fungsi (arteri, kolektor dan lokal), status (nasional, provinsi dan kabupaten atau kota) dan kelas (diatur sesuai ketentuan peraturan perundangundangan di bidang lalu lintas dan angkutan jalan).

\section{METODE PENELITIAN}

Jenis penelitian ini adalah jenis penelitian deskriptif kualitatif dengan menggunakan metode pengumpulan data melalui observasi wawancara. Penelitian ini lebih menekankan pada makna.Menurut Moleong, (2010). Lokasi penelitian merupakan tempat atau wilayah yang digunakan untuk penelitian dengan mendapatkan data-data yang akurat. Penetapan lokasi penelitian merupakan salah satu tahap penting dalam penelitian kualitatif, karena penetapan lokasi penelitian menentukan objek dan tujuan penelitian sehingga mempermudah penulis dalam melakukan penelitian. Penelitian dilakukan di kecamatan Tabir Selatan, Kabupaten Merangin. Miles dan Huberman mengemukakan bahwa: "analisis data dalam penelitian kualitatif, dilakukan pada saat pengumpulan data berlangsung, dan setelah selesai pengumpulan data pada periode tertentu"(Sugiyono, 2016).

\section{HASIL DAN PEMBAHASAN}

Penelitian implementasi kebijakan pembangunan infrastruktur jalan di desa Muara Delang kecamata Tabir Selatan Kabupaten Merangin dengan Menggunakan model Donald Van Metter dan Carl Van Horn menitik beratkan pada enam buah vaeiabel yaitu, standar; tujuan; dan sasaran kebijakan, sumber daya, karakteristik organisasi pelaksana, sikap para pelaksana, komunikasi antar organisasi, lingkungan sosial ekonomi dan politik. Berdasarkan temuan hasil penelitian yang dilakukankan, peneliti akan mendeskripsikan bagimana penagru keenam variabel dalam model donald Van Metter dan Carl Van Horn terhadap implementasi kebijakan pembangunan infrastruktur jalan di kecamatan tabir Selatan kabupaten Merangin.

a) Standar, tujuan, dan sasaran kebijakan Pembangunan infrastruktur jalan di desa muara delang - gading jaya kecamatan Tabir Selatan kabupaten Merangin yang 
Wahyu Kurniawan, Karjuni Dt. Maani| Implementasi Kebijakan Pembangunan Infrastruktur Jalan di Kecamatan Tabir Selatan Kabupaten Merangin dengan Menggunakan Model Donald Van Metter dan Carl Van Horn

rencananya akan dibngun sejauh $9,3 \mathrm{Km}$ dimulai sejak tahun 2017.Tahun 2019 pembanguan sudah menjacapai kurang lebih $8,2 \mathrm{Km}$.

Sejarah mula pembangunan jalan ini berasal dari usulan masyarakat dan perusahaan kelapa sawit yang menginginkan adanya akses jalan yang dapat mempermudah semua kegiatan dalam berbagai bidang kehidupan. Terlebih lagi kondisi jalan yang masih tanah berbatu memburuk saat musim hujan dan kemarau. Jalanan menjadi becek berlumpur hingga banyak kendaraan yang terjebak kedalam lubang- lubang yang dalam sehingga menghambat distribusi barang ataupun mobilitas manusia seperti yang terlihat pada Gambar 2.

\section{Gambar 2. Kondisi Jalan Pasca Hujan}

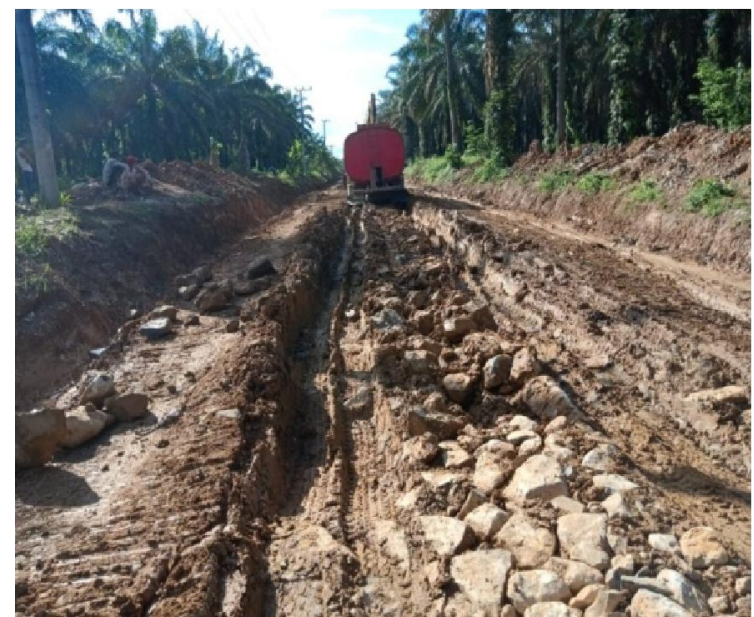

Sumber : Dokumentasi PT. SAL

Saat musim kemarau jalanan dipenuhi dengan debu yang tebal karena banyak mobil-mobil besar yang melewati jalan tersebut seperti pada Gambar 3.

\section{Gambar 3. Kondisi Jalan Berdebu Pasca Kemarau}

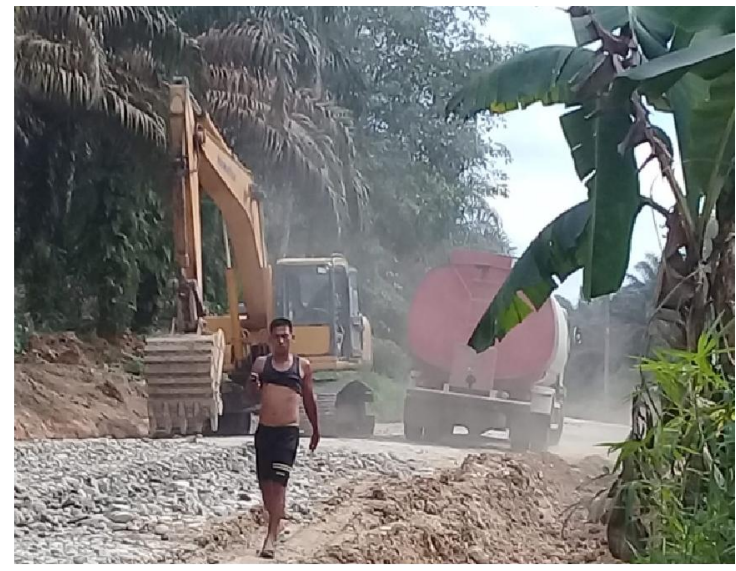

Sumber : Dokumentasi PT. SAL

Jalan di tabir Selatan merupakan jalan yang sering dilewati oleh mobil - mobil dengan muatan yang besar. Mobil-mobil tersebut membawa hasil perkebunan kelapa sawit dan olahan produksi dari peusahaan kelapa sawit yang ada di Tabir Selatan. Mobil dengan muatan yang besar dapat merusak jalan dengan menghasilkan lubang-lubang pada jalan, oleh karena itu penting untuk membuat jalan sesuai dengan standar spesifikasi pemerintah pusat. Adapun satndar jalan yang dibangun merupakan spesifikasi jalan dengan kualitas nomor satu, sehingga jalan tersebut dapat dilewati oleh kendaraan dengan muatan diatas 30 ton/ mobil setiap harinya.

Standar kebijakan pembangunan jalan dengan kualitas baik akan membuat akses mobilisasi barang dan manusia menjadi lebih lancar, keselamatan, ketertiban dan keamanan dalam lalu lintas dapat tercapai. Tujuan dan sasaran dalam kebijakan pembangunan infrastruktur jalan ini adalah untuk aksesabilitas, kelancaran arus barang dan manusia, misalanya mempermudah akses pendidikan, kesehatan dan lain-lain. Meningkatkan perekonomian masyarakan dengan dipermudahnya pengakutan hasil perkebunan kelapa sawit dan 
mempermudah akses masyarakat kepemerintahan kabupaten.

\section{b) Sumber Daya}

Implementasi kebijakan pembangunan infrastruktur jalan di Kecamatan Tabir Selatan dipengaruhi oleh sumber daya manusia, finansial dan waktu. Sumber daya manusia sudah dapat dikategorikan sebagai sumber daya yang berkualitas dan mendukung dalam implementasi kebijakan pembanguna infrastruktur jalan di kecamatan Tabir Selatan. Namun jika dilihat dari faktor finansial dan waktu implementasi kebijakan pembangunan infrastruktur di Kec. Tabir Selatan sedikit terhambat, hal ini dikarenakan oleh beberapa hal seperti :

1) Dana yang tersedia untuk pembangunan infrastruktur jalan digunakan secara bertahap sesuai dengan kontak tahun tunggal, untuk mengelola jalan yang dalam kondisi rusak menjadi baik.

2) Pemerintah pusat akhir-akhir ini sering membebankan pada anggaran daerah dan disisi lain bantuan keuangan dari pusat tidak mengalir lagi kedaerah, ujar Bupati Merangin AL Haris pada salah satu berita kajang lako.com.

\section{c) Karakteristik Organisasi Pelaksana}

Pusat perhatian pada agen pelaksana yang meliputi organisasi formal dan informal yang terdiri atas dinas Pekerjaan umum bina marga, PT. SAL dan PT. Shogun. Karakteristik organisasi pelaksana ini sangat penting karena kinerja implementasi sanagt dipengaruhi oleh ciri yang teapat dan cocok dari para agen pelaksana. Dalam hal ini misalnya dinas pekerjaan umum tatanan pembangunan mengatur penggunaan anggaran dengan
UPTKnya, perusahaan - perusahan yang terlibat dalam pembangunan infrastruktur jalan ikut serta berkontribusi dalam setiap tahapan perencanaan, pembangunan dan pemeliharaan jalan di Tabir Selatan.

Bantuan -bantuan yang diberikan oleh kedua perusahaan, PT. SAL dan PT. Shogun dalam implementasi kebijakan pembangunan jalan ini berupa bantuan alat berat, material dan juga dana. Berdasarkan karakteristik organisasi pelaksana dari donald van metter dan carl van hord, suatu organisasi pelaksana harus bersifat demokratis dan persuasif dalam melaksanakan kebijakan. Demokratis disini maksudnya adalah dalam pelaksanaan implementasi kebijakan para agen pelaksana sebagai perwalikan masyarakat melaksanakan implementasi kebijakan pembangunan infrastruktur jalan di Kecamatan Tabir Selatan dengan baik dan disesuikan dengan sandar, tujuan dan sasaran kebijakan yang ingin dicapai. Sedangkan persuasif disini maksudnya adalah bahwa para agen pelaksana harus dapat mengajak masyarakat dan pihak perusahaan untuk tetap mejaga kondisi jalan agar tetap dalam kondidi mantap.

Dalam pelaksanaannya, implemntasi kebijakan pembangunan infrastruktur jalan di Kecamatan Tabir Selatan memiliki kendala, namun secara keseluruhan masalah tersebut dapat diatasi oleh agen pelaksana sehingga tidak ada masalah yang berlarut-larut.

d) Komunikasi antar organisasi terkait kegiatan-kegiatan pelaksanaan

Suatu kebijakan bisa dilaksanakan dengan efektif, apabila apa yang menjadi standar tujuan dapat dipahami oleh para implementor (individu organisasi pelaksana). Standar dan tujuan harus dikomunikasikan kepada para pelaksana. 
Komunikasi dalam kerangka penyampaian informasi kepada para pelaksana kebijakan tentang apa menjadi standar dan tujuan harus konsisten (Widodo 2008).

Komunikasi antar organisasi ( Dinas PU bina marga, PT. SAL dan Shogun) dari informasi yang diperoleh dari dinas pekerjaan umum adalah lancar dimana dalam prosesnya ada pelaporan secara berkala dan adanya pertemuan-pertemuan antar organisasi terkait pembagian tugas dan tanggung jawab juga membuktikan terjalinnya komunikasi yang baik antar ketiga organisasi pelaksana dalam implemntasi kebijakan pembangunan infrastruktur jalan di Kecamatan Tabir Selatan.

\section{e) Disposisi atau sikap para pelaksana}

Sikap penerimaan atau penolakan dari agen pelaksana sangat mempengaruhi keberhasilan atau kegagalan implementasi kebijakan publik (Agustinus, 2006). Sikap para pelaksana (Dinas PU, PT. SAL, dan PT. Shogun) dalam implemntasi kebijakan pembangunan infrastruktur jalan di Kecamatan Tabir Selatan adalah sangat mendukung. Ketiga organisasi pelaksana maelakukan kegiatan-kegiatan yang mendukung implementasi kebijakan melalui kegiatan perencanaan pembangunan awal dengan melakukan survei lapangan (cek kondisi jalan), memberikan kontribusi berupa material, alat berat dan pendaan selama proses pembangunan jalan. Melakukan pemeliharaan terhadap segmen jalan yang mengalami kerusakan.

Implementasi kebijakan menurut Donald Van Metter dan Carl Van Horn diawali penyaringan persepsi dari para pelaksana . Mealaui tahap penyaringan persepsi ini diketahui ada tiga macam elemen respon yang dapat mempengaruhi kemampuan dan kemauan untuk melaksanakan kebijakan, diantaranya adalah 1)Pengetahuan, pemahaman dan pendalaman terhadap kebijakan, 2) Arah respon mereka apakah menerima, netral atau menolak, dan 3) Intensitas terhadap kebijakan yang dilakukan.

Dari hasil penelitian yang dilakukan ketiga organisasi pelaksana memiliki pengetahuan, pemahaman dan pendalaman terhadap kebijakan yang sangat baik hal ini karena para agen pelaksana sepenuhnya telah menyadari standar dan tujuan dari kebijakan pembangunan imfrastruktur jalan itu sendiri di kecamatan Tabir Selatan Kabupaten Merangin.

Arah respon (disposisi) dari organisasi pelaksana merupakan hal yang "Crucial". Sejak dibangun pada tahun 2017 panjang jalan yang sudah dibangun hingga tahun 2019 ini adalah sekita 8,2 Km. Hal ini menunjukkan bahwa para organisasi pelaksana menerima setiap kebijakan yang dilakukan sehingga intensitas terhadap kebijakan meningkat. Setiap organisasi memiliki peran dan tanggung jawab masing-masing dalam melaksanakan implementasi kebijakan yang telah diputuskan.

Keberhasilan dari implementasi kebijakan dapat dilihat dari penerimaan yang mendalam terhadap standar dan tujuan kebijakan oleh para pelaksana yang dilakukan dengan tanggung jawab dalam melaksanakan kebijakan tersebut. (Kaufman dalam Van Mater dan Van Horn, 1974).

f) Kondisi lingkungan sosial, ekonomi dan politik

Kondisi lingkungan sosial di kecamatan tabir selatan terkait implemntasi kebijakan pembangunan infrastruktur jalan di Kecamatan Tabir Selatan adalah sangat 
mendukung, masyarakat berperan aktif dalam terlaksananya implementasi kebijakn ini mulai dari pengusulan pembangunan jalan, hingga patuhnya masyarakat dalam penggunaan jalan agar proses pembanguna jalan dapat berjalan lancar.

Masyarakat memahami pentingnya pembangunan jalan tersebut untuk meningkatkan kesejahteraan dalam berbagai bidang seperti peningkatan dalam bidang ekonomi, sosial, pendidikan, kesehatan dan lain-lain. Dalam bidang politik adanya implementasi pembangunan infastruktur jalan di kecamtan Tabir Selatan merupakan wujud kehadiran pemerintah dalam meningkatkan kesejahteraan masyarakat.

Dari kondisi sosial, ekonomi dan politik di kecamatan Tabir Selatan ini, kita dapat menilai kinerja implementasi kebijakan pembangunan infrastruktur jalan. sehingga, dari informasi yang diperoleh bahwa kondisi lingkungan eksternal di Tabir Selatan turut mendorong keberhasilan kebijakan.

\section{PENUTUP}

Standar kebijakan pembangunan jalan. Membuat jalan denagn kualitas nomor satu. Agar akses mobilisasi barang dan manusia menjadi lebih lancar, keselamatan, ketertiban dan keamanan dalam lalu lintas dapat tercapai.

Tujuan dan sasaran dalam kebijakan pembangunan infrastruktur jalan: 1) untuk aksesabilitas, kelancaran arus barang dan manusia, misalanya mempermudah akses pendidikan, kesehatan dan lain-lain; 2) Meningkatkan perekonomian masyarakan dengan dipermudahnya pengakutan hasil perkebunan kelapa sawit; 3) Mempermudah akses masyarakat kepemerintahan kabupaten.
Sumber Daya: 1) Sumber daya manusia: sudah mendukung implementasi kebijakan; 2) Sumberdaya finansial: ada, tetapi anggaran dilakukan secara bertahapan setiap satu tahun kontrak; 3) Sumber daya waktu : tergantung kontrak tahun tunggal dan pembiayaan yang ada.

Karakteristik organisasi pelaksana. Berdasarkan karakteristik organisasi pelaksana dari Donald Van Metter dan Carl Van Hord, suatu organisasi pelaksana harus bersifat demokratis dan persuasif dalam melaksanakan kebijakan. Demokratis disini maksudnya adalah dalam pelaksanaan implementasi kebijakan para agen pelaksana sebagai perwalikan masyarakat melaksanakan implementasi kebijakan pembangunan infrastruktur jalan di Kecamatan Tabir Selatan dengan baik dan disesuikan dengan sandar, tujuan dan sasaran kebijakan yang ingin dicapai. Sedangkan persuasif disini maksudnya adalah bahwa para agen pelaksana harus dapat mengajak masyarakat dan pihak perusahaan untuk tetap mejaga kondisi jalan agar tetap dalam kondidi mantap.

Komunikasi antar organisasi terkait kegiatan-kegiatan pelaksanaan lancar. Dalam prosesnya ada pelaporan secara berkala dan adanya pertemuan-pertemuan antar organisasi terkait pembagian tugas dan tanggung jawab juga membuktikan terjalinnya komunikasi yang baik antar ketiga organisasi pelaksana

Disposisi atau sikap para pelaksana. Dari hasil penelitian yang dilakukan ketiga organisasi pelaksana memiliki pengetahuan pemahaman dan pendalaman terhadap kebijakan yang sangat baik hal ini karena para agen pelaksana sepenuhnya telah menyadari standar dan tujuan dari kebijakan pembangunan imfrastruktur jalan di kecamatan Tabir Selatan Kabupaten Merangin merupakan cita-cita dan harapan masyarakat sejak lama. 
Wahyu Kurniawan, Karjuni Dt. Maani| Implementasi Kebijakan Pembangunan Infrastruktur Jalan di Kecamatan Tabir Selatan Kabupaten Merangin dengan Menggunakan Model Donald Van Metter dan Carl Van Horn

Para organisasi pelaksana menerima setiap kebijakan yang dilakukan sehingga intensitas terhadap kebijakan meningkat. Setiap organisasi memiliki peran dan tanggung jawab masing-masing dalam melaksanakan implementasi kebijakan yang telah diputuskan.

Kondisi lingkungan sosial, ekonomi dan politik. Kondisi Sosial : masyarakat berperan aktif dalam terlaksananya implementasi kebijakn ini mulai dari pengusulan pembangunan jalan, hingga patuhnya masyarakat dalam penggunaan jalan agar proses pembanguna jalan dapat berjalan lancar. Masyarakat memahami pentingnya pembangunan jalan tersebut untuk meningkatkan kesejahteraan seperti peningkatan dalam bidang ekonomi, kesehatan, pedidikan, sosial-budaya masyarakat. Dalam bidang politik adanya implementasi pembangunan infastruktur jalan di kecamtan Tabir Selatan merupakan wujud kehadiran pemerintah dalam meningkatkan kesejahteraan masyarakat.

Dilihat dari enam variabel dalam model Donald Van Metter dan Carl Van Horn pada implementasi kebijakan pembangunan infrastruktur jalan dikecamatan tabir Selatan adalah implementasi kebijakan telah sukses.

Dari hasil penelitian ini diketahui bahwa melalui model Donald Van Metter dan Carl Van Horn implementasi kebijakan pembangunan infrastruktur jalan dikecamatan Tabir Selatan telah sukses dilakukan. Pembangunan jalan sejauh 9,3 $\mathrm{Km}$ yang menghubungkan desa Muara Delang-Gading Jaya hampir selesai.alangkah baiknya jika pembanguna tersebut terus dilanjutkan hingga menuju perkotaan.

\section{DAFTAR KEPUSTAKAAN}

Adil Mubarak. (2012). Model Impelementasi Program dalam Upaya Pencapaian Sasaran MDGs 2015 (
Strategi Bagi Birokrasi Sebagai Ujung Tombak Implementasi 8 sasaran MDGs). Repository.Ut.Ac.Id. http://repository.ut.ac.id/2402/1/fisip2 01206.pdf.

Agustino, Leo. 2016. Dasar-dasar Kebijakan Publik.Edisi Revisi. Bandung: Alfabeta.

Ariesto Hadi Sutopo dan Adrianus Arief, 2010. Terampil Mengolah Data Kualitaif. Jakarta. Prenada Media Group.

Effendi, Bachtiar, 2002. Pembangunan Daerah Otonomi Berkeadilan. Jakarta: PT.Ohaido dan Offset.

Endah,dkk. 2017. Implemetasi Kebijakan Pembangunan Infrastruktur Perdesaan. Jurnal Administrasi Publik vol.3,No. 5. Universitas Brawijaya. Malang.

H, Wahyono. 2006. Pengelolaan Prasarana Umum di Kawasan Perbatasan Kota. Jurnal Tata Loka. Vol. 8 No. 1 UNDIP.

Hendra, Julianto. Dkk.2017. Pengaruh pembangunan infrastruktur jalan Terhadap Penataan Kawasan Kumuh Pesisir Kota Tarakan. Jurnal POTENSI. Vol 19 no 02. 2017.

Indra, A Pantau dkk. 2018. Implementasi Pembangunan Infrastruktur Desa Dalam Menunjangaktivitas Perekonomian Masyarakat (Studi di Desa Tempok Selatan Kecamatan Tompaso Kabupaten Minahasa). Jurnal EKSEKUTIF. Volome 1 No. 1. ISSN : 2337-5736. Universitas Sam Ratulangi.

Kepastian.H dan Walid M.S. 2016. Peran Kecamatan dalam Pembangunan Infrastruktur Jalan di Kecamatan Beringin Kabupaten Deli Serdang. Jurnal Ilmu Pemerintahan dan Sosial Politik. Vol. 4. No. 1. UMA. Medan . 
Wahyu Kurniawan, Karjuni Dt. Maani| Implementasi Kebijakan Pembangunan Infrastruktur Jalan di Kecamatan Tabir Selatan Kabupaten Merangin dengan Menggunakan Model Donald Van Metter dan Carl Van Horn

Moleong, Lexy J. 2010. Metodelogi Penelitian Kualitatif. PT Remaja Rosdakarya. Bandung.

Pasolong, Harbani. 2010. Teori Administrasi Publik, Alfabeta, Bandung.

Sabatier, Paul. 1986. "Top down and Bottom up Approaches to Implementation Research". Journal of Public Policy 6, (Jan), h. 21-48.

Soetomo. (2008). Masalah Sosial dan Upaya Pemecahannya. Yogyakarta: Pustaka Pelajar.

Sulaiman, Munandar. 1998. Dinamika Masyarakat Transisi. Pustaka Pelajar. Yogyakarta.

Wahab, Abdul, Solichin. 2012. Analisis Kebijakan. Jakarta: PT. Bumi Aksara.

Widodo, Joko. 2008. Analisis Kebijakan Publik (Konsep dan Aplikasi Proses Kebijkan Publik). Malang. Bayumedia Publishing.

Yonatan, dkk. 2014. Implementasi Pembangunan Infrastruktur Dalam Menunjang Kelancaran Pelayanan Pada Masyarakat Di Kecamatan Mentarang Kabupten Malinau. Jurnal Administrative Reform, Vol.2 No.4,Desember 2014. 